\title{
A Systematic, Hands-On, Reflective, and Effective (SHORE) Approach to Faculty Development for New and Seasoned Faculty
}

Scott E. Hampton

Craig D. Morrow

Ashleah Bechtel

Marjorie H. Carroll

United States Military Academy

The purpose of the faculty development program for teaching Introduction to Psychology in this study is to further develop skills for new and seasoned faculty to enable them to teach and inspire students more effectively. This Systematic, HandsOn, Reflective, and Effective (SHORE) approach provides a forum to practice teaching skills, gain familiarity with course material, incorporate classroom management techniques, evaluate teaching effectiveness, and build a cobesive teaching team. Evaluative feedback indicates the approach positively affects both the faculty and 1,100 students annually. Implications for faculty development programs and research are also discussed.

There are many approaches to developing faculty in higher education. 1 However, when many colleges make attempts to incorporate faculty development programs, Murray (1995) noted that they "tend to rely on a smorgasbord of [ad-hoc] activities rather than a unified plan with clear and coherent strategies based on articulated objectives" (p. 559). Weimer (1997) reviewed the impact of the most common instructional interventions to improve teaching in higher education and found the following to be most effective, in order of effectiveness: personal consultation, teaching workshops/ 
seminars, research grants, peers, and teaching resource materials. Additionally, Mintz (1999) added that faculty development should be more holistic in nature than just "how to teach" workshops. The developmental process should foster social interaction among colleagues, and encompass the values of the institution. As such, a systematic approach to faculty development would strive to integrate pedagogical instruction with hands-on teaching opportunities within the social context of the university and/or department setting.

Another important aspect of faculty development involves reflection on teaching experiences. Allen's (1991) view of a reflective thinking or practitioner program involves information on teaching, guided practice, teaching experience with guided reflection, peer visitations and consultations, consultations with faculty and supervisor, and self-reflection. Ideally, then, this valuable reflective component should also be systematically integrated into a faculty development program.

In addition to the holistic, hands-on, and reflection components, reviews of faculty development literature (Ingram 2001; Murray, 1999) highlighted other effective faculty development components, including a climate that fosters development, a formalized and structured program linked to the institution's mission, linking faculty development to the reward structure, faculty ownership in designing and delivering faculty development, collegial support for good teaching, and a culture of good teaching that is valued by administrators. Thus, effecrive faculty development is far from a smorgasbord of activities to allow faculty to sample. Instead, it should involve a systematic process to maximize faculty development, teaching practice, and reflection within a context that matches the needs and goals of the faculty and institution.

Faculty at West Point typically experience a 30\% turnover of instructors each year, which necessitates a systematic and integrative approach that ensures new instructors are prepared to teach. Like teaching assistants and inexperienced faculty for many other universities, the new instructors at West Point typically assume responsibilities for teaching the introductory undergraduate courses. The current program focuses on the General Psychology Program in the Department of Behavioral Sciences and Leadership at West Point, which developed and implemented an intensive faculty development program for both its new and seasoned faculty. The objective of the program is to produce effective educators through a developmental process that allows participants to practice teaching skills, gain familiarity with course material, incorporate classroom management techniques, evaluate teaching effectiveness, and build a cohesive teaching team. The purpose of this chapter is to 
discuss the Systematic, Hands-On, Reflective, and Effective (SHORE) nature of this faculty development program.

\section{SYSTEMATIC APPROACH}

The faculty development program is conducted primarily during the summer, but continues throughout the year in a four-phase process. Although minor modifications to the program are made annually, the basic structure of the workshop has been found to be an effective means of preparing junior faculty and enhancing the skills of more seasoned faculty. For example, the current program involved four new faculty members who joined eight seasoned faculty members in the General Psychology Program. Through a sponsorship program, seasoned faculty begin a dialogue with the new instructors before they arrive at West Point to familiarize the new instructors with the course, the faculty development process, and the expectations. Additionally, the sponsor will facilitate their transition into the new community. This sponsor will also typically serve as the new instructor's mentor as they go through the first year of professional development in the department, which provides the type of personal consultation common to many of the most effective instructional interventions (Weimer, 1997).

\section{Four Phases}

The program is divided into four distinct phases. The first two phases occur during the new faculty members' first two months at the academy, prior to the start of the fall academic term. The third phase is conducted throughout the fall semester, while the fourth phase is conducted during the spring semester. Each phase has a distinct purpose with respect to faculty development and course curriculum.

Phase I (summer). The first phase is designed to prepare new faculty members for their first teaching assignment in the General Psychology course, or as a refresher for those faculty members who have been away from teaching for a number of years. First, however, the department chair and program managers provide an overview of the department's mission and vision, which illustrate the commitment and value placed on teaching at the academy. Additionally, several activities in the socialization process of new faculty include a walking tour of the campus, recreational softball games, and numerous lunchcons among the faculty. Families also participate in several social activities such as boat rides and picnics.

After the department overview, faculty are instructed in course and lesson design and development using the systematic design of instruction (SDI) 
(Dick, Carey, \& Carey, 2001). This provides faculty members with the tools necessary to develop their own courses and lesson plans and a basic knowledge of how students learn and how to motivate students in the classroom according to Keller's ARCS model of motivation (Keller, 1987a, 1987b). Subsequent activities in the workshop are often linked to this theoretical framework to enhance student learning and motivation in the classroom. Again, new faculty and their sponsors work alongside each other to review and practice the fundamentals of designing instruction.

The remainder of Phase I focuses on course content and practice teaching. Before the new faculty practice teach, however, they review the assessments for each content area, which models the SDI process. The seasoned faculty then model the lessons for the first half of the General Psychology course to the new faculty. Both new and seasoned faculty serve as students for the modeled classes, replicating an actual classroom setting. After the first content area of the course is modeled, the new instructors each practice teach one of the lessons to their peers and the seasoned faculty who serve as their students.

During these lesson models, which are also videotaped, the seasoned faculty also try to model student behaviors in order to practice classroom management techniques. For example, one instructor may try to answer all the questions and another may try to get the instructor to address an irrelevant topic. The goal is to provide the new instructors with opportunities to experience numerous classroom situations in a safe and supportive environment to enhance their confidence and ability to handle such situations as they arise with their students. By the end of Phase I, the new instructors have taught three lessons and seen the lessons and assessments for the first half of the course.

Plsase II (summer). The second phase provides faculty time to prepare their lesson plans for the first half of the course before the fall term begins and continue their orientation to the academy's history, goals, and numerous programs. During this phase, new faculty attend orientations and sometimes literally see many of the activities and events outside of their department that contribute to the academy's mission. For example, they can visit field training of cadets or take a more detailed historical tour of the installation. Spouses are also invited to many of these orientations to facilitate their transition to, and understanding of, the academy. Seasoned faculty and mentors are also available to assist with questions in lesson design and development. In addition to teaching new faculty, the faculty development program fosters collegiality among the new and seasoned faculty and enculturates the new faculty to the mission and values of the institution. 
Phase III (fall). During the fall term, new faculty continue to meet with the seasoned faculty during weekly seminars to share lesson strategies about the second half of the course. These informal discussions provide a forum to discuss various strategies, lessons learned, and teaching practices. Additionally, new faculty can view modeled lessons from a video library, if desired. The course supervisor also visits classes to provide teaching consultations to both new and seasoned faculty.

Again, reinforcing the SDI process, the new faculty review and calibrate the assessments for each content area before they discuss and teach lesson strategies for that area. Because the General Psychology course uses the same exams for all sections, which focus on application of psychology concepts to leadership scenarios through multiple choice and short essay questions, faculty practice grading student exams to calibrate their grading scheme.

Finally, students provide all faculty with midterm and end-of-course ratings to provide feedback to individual instructors. These confidential student ratings are only seen by the instructor, which fosters self-assessment and personal teaching development.

Phase IV (spring). By the start of the spring term, all new faculty have taught for an entire semester and the program focus shifts from teaching to course curriculum. Lessons learned and teaching tips are still shared among the faculty in the weekly meetings. Faculty also continue to calibrate assessments before they teach each content area, as well as gathering student feedback. However, curriculum content now becomes the primary focus. Both new and seasoned faculty review the curriculum of the course to ensure integration of the latest research findings in the field. The course director continues to provide teaching consultations to instructors who also provide peer consultation to each other. Additionally, new and seasoned faculty are videotaped in a teaching lab to continue their self-assessment and to provide videotaped lesson models for future faculty. Thus, this systematic four-phase structure of faculty development in the department is a continuous process that extends throughout the entire year for both new and seasoned faculty. By the end of the spring term, the new faculty have joined the ranks of the sensoned faculty; they then help develop the new faculty when they arrive the following summer. The systematic process continues the cycle of developing a new group of faculty, while at the same time, continuing the development of the seasoned faculty. 


\section{HaNdS-ON Aproach}

The hands-on approach to faculty development reinforces the principle of learning by doing by allowing new faculty to practice teach in authentic classroom situations. Faculty are given time to design lessons to teach and then provided opportunities to practice these lessons in the summer before the fall term begins. An integral and critical aspect of the practice teaching sessions is the practice at providing feedback on teaching practices. During Phase I, seasoned faculty provide feedback to new faculty on their practice teaching lessons. Additionally, the new faculty provide feedback to the seasoned faculty on their modeled lessons. This dual-direction feedback system fosters collegiality among all faculty. Even the most senior faculty are open to candid feedback from new faculty because of their commitment to teaching excellence. This feedback approach continues throughout the academic year as the course director provides feedback to new and seasoned faculty and peers provide feedback to each other.

Another hands-on aspect that illustrates the faculty ownership component (Ingram, 2001; Murray, 1999) is that faculty members within the General Psychology Program in the department conduct the entire faculty development process discussed thus far. The course director solicits input from all faculty when developing the annual development plan and then all available faculty participate in the development plan. Both new and seasoned faculty engage in a systematic and hands-on participatory approach to faculty development.

\section{REFLECTION}

Learning by doing is enhanced through reflection throughout this faculty development program. The hallmark of the faculty development experience in this program is the continuous feedback surrounding the process, which facilitates reflection. As part of the faculty development experience, and in keeping with reflective thinking researchers, the program provides opportunities for faculty to practice teaching and to reflect on strengths, areas of improvement, and instructional strategy, and to share these reflections with other faculty. As described earlier, this faculty development program incorporates all components of Allen's (1991) view of a reflective thinking or practitioner program: 1) information on teaching; 2) guided practice; 3) teaching experience with guided reflection; 4) peer visitations and consultations; 5) consultations with faculty and supervisor; and 6 ) self-reflection. After each modeled or practice teaching lesson in Phase I, faculty reflect on the effectiveness of their strategy with thcir peers and mentor, using a printed checklist as a guide (see 
Appendix 10.1). Both peers and mentors enable all faculty to reflect-in-action and reflect-on-action (Schön, 1987) during the program to enhance the overall effectiveness, learning, and development of new and seasoned faculty. One supervisor of the program often emphasized that the seasoned faculty would actually benefit more from this modeling and feedback process of the workshop than the new faculty (Beach, 1993). Because of the seasoned faculty modeling and openness to feedback, new faculty members are quickly assimilated into the culture of the department and readily accept feedback from other faculty members when they begin to provide instruction.

In addition to allowing new faculty members to exercise the instructional style before a nonjudgmental audience, the practice teaching sessions also serve to enhance new faculty members' self-awareness of their own strengths as well as those areas most likely to profit from further attention. To maximize the utility of these sessions, each period of practice teaching is videotaped for the instructors' own critical review. Because many new faculty members choose to practice teach lessons closely related to their particular area of expertise, the entire faculty receives a de facto workshop on recent developments in a variety of content areas. All participants gain from the innovative strategies and references to the latest research in the field. The day following the practice teaching, the new faculty member will sit down with his or her mentor and reflect upon the feedback received and how to improve the lesson strategy based on that feedback.

Research on effective faculty development interventions note that "[the] ideal type of consultant is a colleague in one's own department who is an upto-date specialist in the specific discipline and who also can serve as a model in instructional methods" (Maxwell \& Kazlauskas, 1992, p. 356). The mentor in this faculty development program fulfills this ideal type of role.

Instructors also reflect on feedback from mid-and end-of-course student surveys. Reviews of student ratings literature reveal that midterm student ratings feedback can have positive impacts on teaching practices, ratings of teaching effectiveness, and student motivation (Cohen, 1980; L' Hommedieu, Menges, \& Brinko, 1990). Receiving such feedback throughout the year facilitates instructor awareness of strengths and weaknesses in their teaching strategies and practices. Most instructors reported that they modified aspects of their classroom strategies as a result of cadet mid-semester feedback. The focus on self-awareness during faculty development is instrumental in allowing faculty to read and act on this feedback without feeling threatened. 


\section{EFFECTIVENESS}

In addition to integrating the six components of effective faculty development programs highlighted in the literature and illustrated throughout this chapter, results from faculty and student surveys point to the success of the department's faculty development program according to pre- and post-tests. The objective of the program is to develop the pedagogical skills of the instructors in general and prepare them to teach General Psychology more effectively during the academic year in particular. The five major goals for Phase I of the program include becoming an effective teacher, being comfortable with course content, incorporating classroom management, evaluating appropriateness and effectiveness of instruction, and working as and feeling like a member of the course faculty team.

Faculty survey results and instructor comments immediately following Phase I illustrate the positive impact of Phase I on preparing new faculty to teach the course. The results summarized below and in Table 10.1 illustrate the new instructors' confidence in their level of preparation and ability to accomplish the workshop objectives. Table 10.1 also illustrates the gain in new faculty confidence from pre- to post-workshop assessment in several objectives.

\section{Goal 1: Become an Effective Teacher}

This goal includes a focus on instructors who are student-centered, influential, value learning, able to provide efficient instruction, and who believe in their ability as well as that of their students. This outcome was measured through the statements "design an instructional strategy," and "implement an instructional strategy," because instructors had to show the aforementioned attributes during their practice teaching or lesson modeling. New faculty rated their feeling of preparedness much higher after Phase $I$ of the program in the summer than they did before they began the program. New instructor written feedback supported this rating:

[The most worthwhile events were] the practice teaching and evaluation. It was immensely important and helpful to see myself on tape and to hear feedback on my class.

The modeled lessons were excellent and the feedback and experience of the practice teach sessions were critical.

I'm 100 times better [at teaching] than 3 weeks ago. 
TABI.E 10.1

New Faculty Survey Questions Before and After Phase I of the Faculty Development Program

\section{New Faculty Survey Questions ( $\mathrm{n}$ - 4) \\ How prepared are you to accomplish the following goals? \\ ( $1=$ Not prepared $3=$ Prepared $5=$ Well prepared $)$ \\ 1. Become an effective teacher \\ a. Design an instructional strategy, given a lesson analysis, the test $\&$ list of available materials \\ b. Implement an instructional strategy}

Pre-

Post-

test

test

2. Be comfortable with course content

N/A*

a. Understand partial and full models of course lessons

b, Practice teach course lessons

3. Incorporate classroom management

N/A*

4.75

Incorporate the following into the classroom:
a. Films/TV clips in classes
b. Conferences/discussions
c. Role-playing exercises
d. Practical exercises
c. Practice integrating exercises
f. Classroom administrative procedures

4. Evaluate appropriateness and effectiveness of instruction
a. Administer tests
b. Grade tests

5. Work and feel as a member of the course faculty team

Rate each activity according to how well it prepared you to accomplish the following goals

N/A*

( 1 = Unsatisfactory $3=$ Avcrage $5=$ Outstanding)

1. Department welcome orientation

2. Course orientation

3. Systematic Design of Instruction (SDI)

4. Teaching strategies

5. Administrative policies and procedures

6. Content area overviews

7. Partial class models and feedhack

8. Full class modcls and feedback

9. Practice teaching and fecdback

10. Exam review before covering the content area

11. Exam calibration

- N/A because pretest administered before exposure to modeled classes and practice teaching. 


\section{Goal 2: Be Comfortable With Course Content}

This goal involves instructors becoming subject matter experts by utilizing returning faculty or outside sources as resources, as well as practice teaching and giving feedback to returning faculty. This outcome was measured with ratings of the instructor's understanding of material covered in class models and practice teaching. New faculty rated their level of preparedness to teach the course as high.

\section{Goal 3: Incorporate Classroom Management}

Instructors must plan their classes, be prepared, have organized instructional activities, and most importantly, stay on time and on task. This outcome was measured through ratings in the following areas: classroom administration procedures, incorporation of films, role-playing exercises, practical exercises, and integrated performance objectives. Again, new faculty rated their level of preparedness in this area as high.

\section{Goal 4: Evaluate the Appropriateness and Effectiveness of Instruction}

Instructors are able to evaluate individual strengths and weaknesses in teaching throughout the year. The survey question, "Evaluate the appropriateness and effectiveness of instruction," assessed this objective. New faculty rated their level of preparedness as quite low before Phase I and much higher after Phase I. Written feedback supported this rating. One new instructor wrote:

I now have an understanding of how active learning is incorporated into our lesson. These activities also allowed me to identify what will be difficult for the cadets, possible trouble spots I may encounter and various strategies that seem to work well.

\section{Goal 5: Work and Feel Like a Member of the Course Faculty Team}

Instructors feel like part of the team and have pride in the department. The survey question, "Work and feel as a member of the PL100 committee team," assessed this objective, which received a perfect " 5 " rating from the new faculty. Again, written feedback also supported this rating. For example, one new instructor wrote: "The mentor program was the most enjoyable part of the program. It enabled me to thoroughly study and observe the lesson development process." Evidence of the collegiality of the new and seasoned faculty is summarized by two new instructors' comments about what they liked most about the workshop: 
I felt welcome and that the previous years' instructors really want us here.

The feeling of safety. It was OK to make mistakes and I was offered opportunities to correct mistakes or come up with alternate strategies.

Thus, survey results and new instructor comments seem to indicate that the program was very effective for preparing the new faculty to teach and also integrating them into the department faculty team. When specifically asked to rate each activity from $P$ hase $I$ of the program according to how well it prepared you to accomplish the program goals, the average rating for all activities was 4.75 on a 5-point Likert scale with 5 representing "outstanding" (see Table 10.1).

To assess the effectiveness of the faculty development program, we also looked toward the students and their performance and attitudes toward their instructors and the General Psychology course. Ideally, effective teachers should have a positive impact on student learning and student attitudes (Reiser \& Dick, 1996). Seldin (1999) claims that student ratings are the most prevalent source of evaluating teaching effectiveness in higher education and McKeachie (1997) adds, "Student ratings are the single most valid source of data on teaching effectiveness" (p. 1219). Additionally, reviews of the literature reveal that student ratings of particular outcomes are positively related to learning outcomes. Thus, we examined the impact of the faculty development program on student attitudes through student ratings (Cohen, 1980; Feldman, 1989).

One way to measure student learning is the successful completion of the course. In a typical year, less than ten students in 1,100 will fail the course, which is an overall pass rating of over $99 \%$. The class average for the General Psychology course, which requires cadets to demonstrate content knowledge and application of that content, is typically near $83 \%$, a " $B$ " average.

Additionally, one of the academic goals for the academy is understanding of human behavior (USMA Academic Board and Office of the Dean, 1998). On an end-of-course student survey, the majority of students responded "agree" or "strongly agree" to the statements "It was important for me to learn and master all that I could from this course" and "I think I can apply concepts I learned in the course later in life and career." Overall, students felt they gained an understanding of human behavior and how to apply it in their future roles.

End-of-course student ratings also reveal that instructors who participated in this workshop were rated higher than the academy average in many areas, such as instructor encouragement, enthusiasm and motivation, stimulation of 
critical thinking skills, class preparedness, concern with student learning, and mastery of subject material. Four of these rating dimensions were significantly different $(p<.01)$. What makes this difference interesting, however, is the institutional requirement at West Point that all academic departments have new instructor faculty development programs before the academic year begins. Higher ratings in the Department of General Psychology may be due to the combined effects of the systematic approach, practical hands-on experiences, feedback, and reflection upon those experiences throughout the academic year. On the other hand, it could also be due to the nature of the interesting and relevant content taught to freshman in introductory psychology. Incidentally, one rating on fellow students' contributions to learning was significantly lower than the academy mean. This could be due to the individual learning emphasis in such an introductory course as compared to many other upper class courses that tend to have more collaborative projects.

Table 10.2 also illustrates extremely favorable student responses to departmental questions on instructor enthusiasm, communication, and lesson structure. The modeling of lessons by seasoned faculty seems to have a positive influence on new instructor lesson planning and delivery as evident by the extremely high student rating of 4.91 to the question "My instructor had a structure or plan for every lesson's learning activities." A sample of additional student comments to the question "What comments or suggestions would you like to leave with your instructor?" includes:

I really enjoyed your class. It was my favorite Academic course of my plebe [freshman] year and I learned a great deal about myself, others, and how I can apply this knowledge as a learner in the Army. Thanks.

Your enthusiasm helped remind me why I'm at this school and showed me the type of leader I want to become.

The faculty development program, then, secms to produce confident and competent faculty that students notice and positively regard.

\section{RECOMMENDATIONS}

Although it may not be feasible for every university to operate a faculty development program to the degree that this program has at West Point, it is possible for faculty members to take pieces of this exemplar and fit it to meet their institutional needs. If new instructors do not arrive until just before the semester, seasoned faculty members could coach and mentor them into the 
TABLE 10.2

A Comparison of Student Survey Responses Between USMA Courses and Psychology Course ${ }^{1}$

\begin{tabular}{|c|c|c|c|c|c|}
\hline \multirow[t]{2}{*}{ USMA Questions ${ }^{2}$} & \multicolumn{2}{|c|}{ USMA } & \multicolumn{3}{|c|}{ Psychology } \\
\hline & M & SD & M & SD & $\mathrm{T}$ \\
\hline $\begin{array}{l}\text { 1) This instructor encouraged students to be } \\
\text { responsible for their own learning. }\end{array}$ & 4.48 & .64 & 4.52 & .57 & 1.68 \\
\hline $\begin{array}{l}\text { 2) This instructor used effective techniques } \\
\text { for learning, both in class and for out-of- } \\
\text { class assignments. }\end{array}$ & 4.22 & .9 & 4.61 & .57 & ${ }^{*} 16.36$ \\
\hline $\begin{array}{l}\text { 3) My instructor cared about my learning } \\
\text { in this course. }\end{array}$ & 4.45 & .75 & 4.72 & .51 & $* 12.66$ \\
\hline $\begin{array}{l}\text { 4) My instructor demonstrated respect for } \\
\text { caders as individuals. }\end{array}$ & 4.57 & .68 & 4.8 & .46 & $* 11.96$ \\
\hline $\begin{array}{l}\text { 5) My fellow students contributed to my } \\
\text { learning in this course. }\end{array}$ & 3.99 & .94 & 3.87 & .85 & $*-3.38$ \\
\hline $\begin{array}{l}\text { 6) My motivation to learn and to continue } \\
\text { learning has increased because of this course. }\end{array}$ & 3.92 & 1.05 & 4.02 & .87 & 1.13 \\
\hline 7) This instructor stimulated my thinking. & 4.22 & .86 & 4.47 & .64 & *9.34 \\
\hline $\begin{array}{l}\text { 8) In this course, my critical thinking ability } \\
\text { increased. }\end{array}$ & 4.01 & .94 & 4.06 & .81 & 1.48 \\
\hline Program Only Questions & & & M & $\mathrm{SD}$ & \\
\hline $\begin{array}{l}\text { 9) My instructor communicated effectively } \\
\text { (e.g., appropriate level, spoke clearly, } \\
\text { inflections, etc.). }\end{array}$ & & & 4.76 & .51 & \\
\hline $\begin{array}{l}\text { 10) My instructor was enthusiastic and energetic } \\
\text { when presenting course material. }\end{array}$ & & & 4.75 & .57 & \\
\hline $\begin{array}{l}\text { 11) My instructor had a structure or plan for } \\
\text { every lesson's learning activities. }\end{array}$ & & & 4.91 & .3 & \\
\hline $\begin{array}{l}\text { 12) My instructor was concerned with my } \\
\text { learning (c.g., encouraged questions and } \\
\text { discussion, encouraged AI when appropriate, } \\
\text { seemed approachable for help). }\end{array}$ & & & 4.79 & .46 & \\
\hline $\begin{array}{l}\text { 13) My instructor showed me ways in which the } \\
\text { course was of practical significance and } \\
\text { applicable in my future (e.g.. military } \\
\text { applications, future course applications, } \\
\text { or common applications). }\end{array}$ & & & 4.66 & .53 & \\
\hline $\begin{array}{l}\text { 14) My instructor helped motivate me to do } \\
\text { my best work and gain maximum benefit } \\
\text { from the course. }\end{array}$ & & & 4.41 & .72 & \\
\hline
\end{tabular}

1 Represent Mcan scores for 12 inseructors

2 Scale range: $I=$ Strongly disagree to $5=$ Strongly Agree

*p<.001 
department. These new instructors could then shadow seasoned faculty to observe them teaching classes. Likewise, the seasoned faculty members could observe new instructors teaching or review videotapes of their classes to provide valuable and supportive feedback and reflection opportunities.

Researching the specific aspects of faculty development is a worthwhile endeavor. The program described in this chapter has evolved into its current state over many years. Soliciting feedback from faculty and students and analyzing such feedback and student performance continually helps improve the efficiency and effectiveness of the faculty development process. A critical and efficient aspect of this program is that it is entirely resourced by the academic department, with the institutional support and priority given to faculty development by the academy dean and department head.

\section{Disclaimer}

The views presented in this chapter are those of the authors and do not necessarily represent the views of the Department of Defense or its components.

\section{REFERENCES}

Allen, R. R. (1991). Encouraging reflection in teaching assistants. In J. D. Nyquist, R. D. Abbott, D. H. Wulff, J. \& Sprague (Eds.), Preparing the professorate for tomorrow to teach: Selected readings in TA training (pp. 323-317). Dubuques, IA: Kendall/Hunt.

Beach, J. (1993, Summer). Address to faculty. Department of Behavioral Sciences and Leadership, West Point, NY.

Cohen, P. A. (1980). Effectiveness of student-rating feedback for improving college instruction: A meta-analysis of findings. Research in Higher Education, 13, $321-341$.

Dick, W., Carey, L., \& Carey, J. (2001). The systematic design of instruction (5th ed.). Boston, MA: Addison, Wesley, \& Longman.

Feldman, K. A. (1989). The association between studene ratings of specific instructional dimensions and student achievement: Refining and extending the syntheses of data from multisection validity studies. Research in Higher Education, $3066), 583-645$.

Ingram, K. (2001). The effects of reflective thinking training on TAs' reflective thinking, use of instructional activities, instructional effectiveness, motivation to teach and cheir students' attitudes toward instruction. (Doctoral Dissertation, Florida State University, 2001). Dissertation Abstracts International, 62(2), 486. 
Keller, J. M. (1987a). Strategies for stimulating the motivation to learn. Performance \& Instruction, 26, 1-7.

Keller, J. M. (1987b). The systematic process of motivational design. Performance $\&$ Instruction, 26, 1-8.

L' Hommedieu, R., Menges, R., \& Brinko, K. (1990). Methodological explanations for the modest effects of feedback. Journal of Educational Psychology, 82, 232-241.

Maxwell, W. E., \& Kazlauskas, E. J. (1992). Which faculty development methods really work in community colleges? A review of research. Community Junior College Quarterly, 16, 351-360.

McKeachie, W. J. (1997). Student ratings: The validity of use. American Psychologist, $52,1218-1225$.

Mintz, J. M. (1999, Spring). Faculty development and teaching: A holistic approach. Liberal Education, 85(2), 32-37.

Murray, J. P. (1995). Faculty (mis)development in Ohio two-year colleges. Community College Journal of Research and Practice, 19, 549-563.

Murray, J. P. (1999). Faculty development in a national sample of community colleges. Community College Review, 27(3), 47-64.

Reiser, R., \& Dick, W. (1996). Instructional planning: A guide for teachers (2nd ed.). Boston, MA: Allyn and Bacon.

Schön, D. A. (1987). Educating the reflective practitioner: Toward a new design for teaching and learning in the professions. San Francisco, CA: Josscy-Bass.

Seldin, P. (1999). Current practices-good and bad-nationally. In P. Seldin \& Associates, Changing practices in evaluating teaching: $A$ practical guide to improved faculty performance and promotion/tenure decisions (pp. 1-24). Bolton, MA: Anker.

USMA Academic Board and Office of the Dean. (1998). Educating army leaders for the 2 Ist century. West Point, NY: United States Military Academy.

Weimer, M. (1997). Exploring the implications: From rescarch to practice. In R. P. Pcrry \& J. C. Smart (Eds.), Effective teaching in higher education: Research and practice (pp. 411-435). New York, NY: Agathon. 


\section{Contact:}

LTC Scort E. Hampton

Department of Behavioral Sciences and Leadership

United States Military Academy

West Point, NY 10996

Voice (845) 938-5637

Email LS0425@usma.edu

Major Craig D. Morrow

Department of Behavioral Sciences and Leadership

United States Military Academy

West Point, NY 10996

Voice (845) 938-4806

Email LC4122@usma.edu

Major Ashleah Bechtel

Chief, Specialized Training Management Branch

Total Army Personnel Command

Alexandria, VA 22314

Email Ashleah.Bechtel@hoffman.army.mil

Marjorie H. Carroll

Department of Behavioral Sciences and Leadership

Unired States Military Academy

West Point, NY 10996

Voice (845) 938-5642

Email LM5467@usma.edu

LTC Scott E. Hampton, PhD, is a career officer in the United States Army. He currently serves as an Assistant Professor at the United States Military Academy and is responsible for teaching caders and officers on topics related to psychology, teaching, training, and leadership. His research interests include student ratings feedback, instructional consultation, faculty development, and teaching. His doctorate is in instructional systems from Florida State University.

Major Craig D. Morrow is a career officer in the United States Army. Currently assigned as an Assistant Professor at the United States Military Academy, he teaches Developmental Psychology and General Psychology. He earned his graduate degree in developmental psychology from the Pennsylvania State University.

Major Ashleah Bechtel entered the United States Army in 1991 as an Adjutant General Corps officer. She is currently responsible for managing all specialized training for cnlisted soldiers to include the noncommissioned officer education system. 
While assigned to the United States Military Academy she taught psychology and counseling. Her research interests include eating disorders, military families and stress, and faculty development. She received her master's in counselor education from the University of North Carolina at Greensboro.

Marjorie H. Carroll is Assistant Professor of Psychology at the United States Military Academy. She is responsible for teaching introduction to psychology, research methods and statistics, theories of personality, and abnormal psychology. Her research interests are in the areas of memory and attributions of responsibility in rape scripts. She received her doctorate in clinical psychology from St. John's University. 